\title{
EXCHANGEABLE ALUMINUM EVALUATION IN ACID SOILS
}

\author{
Cassio Hamilton Abreu Jr. ${ }^{*}$; Takashi Muraoka²; André Fernando Lavorante ${ }^{3}$ \\ ${ }^{1}$ USP/CENA - Lab. de Nutrição Mineral de Plantas, C.P. 96 - 13400-970 - Piracicaba, SP - Brasil. \\ ${ }^{2}$ USP/CENA - Lab. de Fertilidade do Solo. \\ ${ }^{3}$ USP/CENA - Lab. de Química Analítica. \\ *Corresponding author <cahabreu@cena.usp.br>
}

\begin{abstract}
One of the main factors limiting agricultural production in tropical climate regions is mainly related to the presence of exchangeable aluminum $\left(\mathrm{Al}^{3+}\right)$ in highly weathered acid soils. Four methods of $\mathrm{Al}^{3+}$ determination extracted with neutral $1 \mathrm{~mol} \mathrm{~L}^{-1} \mathrm{KCl}$ solution were evaluated: three colorimetric methods (aluminon plus ascorbic acid, and eriochrome cyanine R by FIA) and the usual titrimetric method with backtitration. Surface samples from 20 soils of different Brazilian regions, with active acidity $\left(0.01 \mathrm{~mol} \mathrm{~L}^{-1} \mathrm{CaCl}_{2}\right.$ $\mathrm{pH}$ ) ranging from very high to medium (3.82 to 5.52), were used. The variance analysis revealed significant interaction among $\mathrm{Al}^{3+}$ determination methods and soil. Mean methods comparisons within each soil (Tukey, $P<0.05)$ indicated that, for most of the soils, the methods differed among each other, although there were high correlations between the obtained values. $\mathrm{Al}^{3+}$ values determined for soil samples by titration varied between 0.15 and $14.71 \mathrm{mmol}_{\mathrm{c}} \mathrm{dm}^{-3}$. The colorimetric methods showed higher values than the titration method, mainly for those with aluminon (up to $18.75 \mathrm{mmol}_{\mathrm{c}} \mathrm{dm}^{-3}$ ). The $\mathrm{Al}^{3+}$ contents of colorimetric methods correlated quadraticaly with the titration values, for the soil samples with $\mathrm{Al}^{3+}>10 \mathrm{mmol} \mathrm{dm}^{-3}$. Among colorimetric methods, in operational terms, the eriochrome with FIA method presented analytical performance up to 50 samples per hour, easiness and sensibility for routine $\mathrm{Al}$ analysis in soil samples. However, due to the specificity, the titration/back-titration method should be used, despite the moroseness, when the $\mathrm{Al}^{3+}$ ions are the objective. Key words: FIA, aluminon, colorimetry, eriochrome cyanine R, titrimetry
\end{abstract}

\section{AVALIAÇÃO DE ALUMÍNIO TROCÁVEL EM SOLOS ÁCIDOS}

\begin{abstract}
RESUMO: Um dos principais fatores que afetam a produção agrícola em regiões de clima tropical, é a presença de alumínio trocável $\left(\mathrm{Al}^{3+}\right)$ em solos ácidos altamente intemperizados. Foram avaliados quatro métodos de determinação de alumínio trocável em solução neutra de $\mathrm{KCl} 1 \mathrm{~mol} \mathrm{~L}^{-1}$ : três métodos colorimétricos (aluminon, aluminon + ácido ascórbico e eriocromo cianina R por FIA) e o método titulométrico usual com retrotitulação ácida. Para obtenção dos extratos de $\mathrm{KCl}$, foram usadas amostras superficiais de 20 solos de diferentes regiões brasileiras, com acidez ativa $\left(\mathrm{pH} \mathrm{em} \mathrm{CaCl}_{2} 0,01 \mathrm{~mol} \mathrm{~L}^{-1}\right)$ variando de muito alta a média $(3,82$ a 5,52). A análise de variância revelou interação significativa entre os métodos de determinação e amostras de solos. O teste de médias (Tukey, $P<0,05$ ) de métodos dentro de amostras evidenciou, para a maioria das amostras de solos, que os métodos analíticos diferenciaram entre si, embora tenha havido forte correlação entre os valores obtidos. Os valores de $\mathrm{Al}^{3+}$ determinados por titulação variaram de 0,15 a 14,71 mmol $\mathrm{dm}^{-3}$. Os métodos colorimétricos apresentaram valores superiores aos da titulação, notadamente aqueles com aluminon (até $18,75 \mathrm{mmol}_{\mathrm{c}} \mathrm{dm}^{-3}$ ). Os teores de $\mathrm{Al}^{3+}$ dos métodos colorimétricos se relacionaram quadraticamente com os teores obtidos por titulação, em amostras de solos com $\mathrm{Al}^{3+}>10 \mathrm{mmol}_{\mathrm{c}} \mathrm{dm}^{-3}$. Dentre os métodos colorimétricos, o reagente eriocromo cianina $\mathrm{R}$, em sistema FIA, mostrou-se operacionalmente confiável e eficiente para a análise de $\mathrm{Al}$, de amostras de solos, em rotina, com freqüência analítica de 50 determinações por hora. Todavia, devido à especificidade, o método titulométrico com retrotitulação deve ser usado, não obstante a morosidade, quando o objetivo é a determinação do íon $\mathrm{Al}^{3+}$.

Palavras-chave: FIA, aluminon, colorimetria, eriocromo cianina $\mathrm{R}$, titulometria
\end{abstract}

\section{INTRODUCTION}

In acid mineral soils of tropical climate regions, the high aluminum $(\mathrm{Al})$ content, associated to high acidity and low fertility, is one of the main constraints for agricultural production (McLean, 1965; Pavan, 1983; Coscione et al., 1998), since toxic concentrations of $\mathrm{Al}$ are often concerned as having detrimental effects on plants.
At soil $\mathrm{pH} 4$ or bellow, the predominant aluminum form is $\mathrm{Al}^{3+}$. As soil $\mathrm{pH}$ increases mononuclear hydrolysis species such as $\mathrm{Al}(\mathrm{OH})^{2+}$ and $\mathrm{Al}(\mathrm{OH})_{2}^{+}$are formed. If $\mathrm{pH}$ increases high enough, these species are precipitated as $\mathrm{Al}(\mathrm{OH})_{3}{ }^{0}$, and with further increases in $\mathrm{pH}$, the amphoteric $\mathrm{Al}(\mathrm{OH})_{4}^{-}$species appears (Barnhisel \& Bertsch, 1982; Thomas \& Hargrove, 1984). There are contradicting results on the relative phytotoxicity of 
mononuclear $\mathrm{Al}$ species, except for the nonphytotoxicity of $\mathrm{Al}(\mathrm{OH})_{4}^{-}$(Marschner, 1997).

The extraction of $\mathrm{Al}^{3+}$ (usually called as exchangeable $\mathrm{Al}$ ) from soil samples using neutral solutions of nonbuffered salts has been employed since the 1960's (Brauner, 1966). The $1 \mathrm{~mol} \mathrm{~L}^{-1} \mathrm{KCl}$ solution has been considered the most appropriate extractant (McLean, 1965; Raij et al., 1987; Hiradate et al., 1998), besides the fact of this solution being less susceptible to ion interferences (Coscione et al., 1998). The $\mathrm{Al}^{3+}$ determined in these extracts is subject to overestimation due to the dissolution of non-exchangeable aluminum species (hydroxi-Al). The dissolution of hydroxi-Al species is affected by $\mathrm{pH}$, concentration, and chemical feature of the extractant, as well as the extraction time (Kissel et al., 1971; Oates \& Kamprath, 1983). Although the extraction with $\mathrm{KCl}$ removes both exchangeable and some nonexchangeable Al (Oates \& Kamprath, 1983), the contribution of non-exchangeable Al may be considered insignificant in Brazilian acid soils (Pavan, 1983).

The $\mathrm{Al}^{3+}$ is always displaced from exchange sites by non-buffered salt solutions. Since the soil $\mathrm{pH}$ raises and monomers are formed, there gradually occur increments on the $\mathrm{OH} / \mathrm{Al}$ relation and of the polymerization of these monomers. The formed polymers, of variable size and charges, neutralize negative charges but are not displaced (Thomas \& Hargrove, 1984). Despite of this, expressive amounts of low stability hydroxi-Al forms are supposed to occur in $\mathrm{KCl}$ extracts. The hydrogen ions $\left(\mathrm{H}^{+}\right)$, obtained by titration in $\mathrm{KCl}$ extracts of an acid mineral soil containing 1:1 clay minerals and $\mathrm{Al}, \mathrm{Fe}$ oxides, are indeed a result of low stability hydroxi-Al hydrolysis. According to Kissel et al. (1971), the lower the hydroxi-Al form contents, the higher is the proportion of their hydrolysable forms, due to lower polymerization (stability) of these $\mathrm{Al}$ forms, which produce $\mathrm{H}^{+}$in $\mathrm{KCl}$ extract. Consequently, as the back-titration step is essential when $\mathrm{Al}^{3+}$ determination in $\mathrm{KCl}$ extract is the main target, the titrimetric method should be used.

Although the $\mathrm{Al}^{3+}$ in soil samples is generally determined by titrimetry (McLean, 1965; Raij et al., 1987; Coscione et al., 1998), colorimetric methods can also be used (Raij et al., 2001). Among the colorimetric methods, the aluminon (Frink \& Peech, 1962; Brauner, 1966; Reis, 1978) and the eriochrome cyanine R (Reis, 1978; Zagatto et al., 1981; Pavan, 1983) are the most commonly used reagents.

Bertsch et al. (1981) and Barnhisel \& Bertsch (1982), employing the aluminon colorimetric method for $\mathrm{Al}$ determination in soil extracts, reported low detection limits $\left(2 \mu \mathrm{mol} \mathrm{L}^{-1}\right)$ and analytical interference of the ferric ion, which is also complexed by the reagent. According to Hawke \& Powell (1994), ferric ions do not constitute impediment for using aluminon, since the interference caused by the ion can be eliminated with ascorbic acid treatment.
The titrimetric method may present inferior sensitivity in relation to the colorimetric methods for the determination of $\mathrm{Al}$ (Reis, 1978; Logan et al., 1985), but it is less subject to interferences from ions present in the extract (McLean, 1965; Coscione et al., 1998). Both titrimetric and colorimetric methods present low determination rates in face of the intrinsic slowness of these methods. Therefore, the determination of Al by colorimetry through flow injection analysis (FIA) using eriochrome cyanine $\mathrm{R}$ has been suggested (Zagatto et al., 1981; Kronka, 1996).

The objective of this work is to compare titrimetric (standard) and colorimetric methods, with aluminon, aluminon plus ascorbic acid (conventional) and eriochrome cyanine $\mathrm{R}$ using FIA system, for the determination of $\mathrm{Al}^{3+}$ in different extracts by $1 \mathrm{~mol} \mathrm{~L}^{-1} \mathrm{KCl}$ of Brazilian soil samples, to improve routine analysis.

\section{MATERIAL AND METHODS}

The experiment was carried out using samples of the surface layer $(0-0.2 \mathrm{~m}$ depth) of 20 soils from different Brazilian regions (Table 1).

Air dried samples were homogenized, divided into three subsamples, ground in a porcelain crucible, passed through a $0.5 \mathrm{~mm}$ mesh sieve, and conditioned in plastic bags. For the chemical characterization of soil samples (Table 2), the methods described in Raij et al. $(1987 ; 2001)$ were used, except for the exchangeable sodium which was extracted with $0.05 \mathrm{~mol} \mathrm{~L}^{-1} \mathrm{HCl}+0.0125$ mol L-1 $\mathrm{H}_{2} \mathrm{SO}_{4}$ solution in 1:5 (v/v) soil/extractant ratio and determined by flame photometry.

For the evaluation of the $\mathrm{Al}^{3+}$ in the extracts of $1 \mathrm{~mol} \mathrm{~L}^{-1} \mathrm{KCl}$ solution, 1:10 (v/v) soil/solution ratio (McLean, 1965), the following procedures were used: a) Titrimetric method (standard method), according to the routine methodology adapted from McLean, (1965). Primarily, the exchangeable acidity $\left(\mathrm{Al}^{3+}+\mathrm{H}^{+}{ }_{\text {tit }}\right)$ is determined by titration of $25 \mathrm{~mL} \mathrm{KCl}$ extract with $0.025 \mathrm{~mol} \mathrm{~L}^{-}$ ${ }^{1} \mathrm{NaOH}$, using $1 \mathrm{~g} \mathrm{~L}^{-1}$ phenolphthalein as an indicator (titration from colorless to pink). Then, the concentration of $\mathrm{Al}^{3+}$ is obtained by back-titration of the same $\mathrm{KCl}$ extract, previously used, after the acidification with a drop of $\mathrm{HCl}$ and addition of $40 \mathrm{~g} \mathrm{~L}^{-1} \mathrm{NaF}$, with $0.025 \mathrm{~mol} \mathrm{~L}^{-1}$ $\mathrm{HCl}$ (titration from pink to colorless); b) Colorimetric methods with aluminon (ammoniacal salt of aurintricarboxilic acid) according to Wolf (1982), adapted for the $\mathrm{KCl}$ solution (e.g., $1 \mathrm{~mL}$ of $\mathrm{KCl}$ extract, $0.4 \mathrm{~mL}$ of sodium phosphate, $1 \mathrm{~mL}$ hydroxylamine hydrochloride, and $3 \mathrm{~mL}$ of aluminon solution). The intensity of developed color is read in a spectrophotometer at $555 \mathrm{~nm}$, zeroing the equipment with the blank $\left(1 \mathrm{~mol} \mathrm{~L}^{-1} \mathrm{KCl}\right)$; c) Modified aluminon colorimetric methods by addition of ascorbic acid to verify the effect of adding $1 \mathrm{~mL}$ of $20 \mathrm{~g} \mathrm{~L}^{-1}$ ascorbic acid (prepared immediately before the 
Table 1 - Legend, classification, and origin of the soil samples used in the experiment.

\begin{tabular}{|c|c|c|c|c|}
\hline $\begin{array}{l}\text { Soil sample } \\
\text { legend }\end{array}$ & $\begin{array}{l}\text { Soil classification (Estados Unidos, 1999; FAO, 1994; Embrapa, 1999; } \\
\text { respectively) }\end{array}$ & Municipality & $\begin{array}{l}\text { Geographic } \\
\text { coordinate }\end{array}$ & State \\
\hline GX & Typic Umbraquult/Dystric Gleisol/Gleissolo Háplico Tb Distrófico & Iranduba & $\begin{array}{l}3^{\circ} 14^{\prime} 05^{\prime \prime} \mathrm{S} \\
60^{\circ} 11^{\prime} 10^{\prime \prime} \mathrm{W}\end{array}$ & $\mathrm{AM}$ \\
\hline LA- 1 & Typic Acrudox/Geric Ferralsol/ Latossolo Amarelo Acriférrico & Viçosa & $\begin{array}{l}9^{\circ} 22^{\prime} 14^{\prime \prime} \mathrm{S} \\
36^{\circ} 14^{\prime} 27^{\prime \prime} \mathrm{W}\end{array}$ & MG \\
\hline LV-1 & Typic Hapludox/Rhodic Ferralsol/ Latossolo Vermelho Distroférrico & Três Lagoas & $\begin{array}{l}20^{\circ} 45^{\prime} 04^{\prime \prime} \mathrm{S} \\
51^{\circ} 40^{\prime} 42^{\prime \prime} \mathrm{W}\end{array}$ & MS \\
\hline LV-2 & Typic Acrudox/Geric Ferralsol/ Latossolo Vermelho Acriférrico & Cuiabá & $\begin{array}{l}15^{\circ} 35^{\prime} 46^{\prime \prime} \mathrm{S} \\
56^{\circ} 05^{\prime} 48^{\prime \prime} \mathrm{W}\end{array}$ & MT \\
\hline LA-2 & Typic Hapludox/Xantic Ferralsol/ Latossolo Amarelo Distrófico & Capitão Poço & $\begin{array}{c}1^{\circ} 44^{\prime} 47^{\prime \prime} \mathrm{S} \\
47^{\circ} 03^{\prime} 34^{\prime \prime} \mathrm{W}\end{array}$ & PA \\
\hline PVA-1 & Typic Hapludult/Haplic Acrisol/ Argissolo Vermelho-Amarelo Distrófico & Capitão Poço & $\begin{array}{l}1^{\circ} 44^{\prime} 47^{\prime \prime S} \\
47^{\circ} 03^{\prime} 34^{\prime \prime} \mathrm{W}\end{array}$ & PA \\
\hline LA-3 & Typic Hapludox/Xantic Ferralsol/ Latossolo Amarelo Distrófico & Ipixuna & $\begin{array}{l}2^{\circ} 33^{\prime} 28^{\prime \prime} \mathrm{S} \\
47^{\circ} 29^{\prime} 42^{\prime \prime} \mathrm{W}\end{array}$ & PA \\
\hline LA-4 & Typic Hapludox/Xantic Ferralsol/ Latossolo Amarelo Distrófico & Ipixuna & $\begin{array}{c}2^{\circ} 33^{\prime} 28^{\prime \prime} \mathrm{S} \\
47^{\circ} 29^{\prime} 42^{\prime \prime} \mathrm{W}\end{array}$ & PA \\
\hline NV-1 & Typic Kandiudult/Rhodic Ferralsol/ Nitossolo Vermelho Distroférrico & Maringá & $\begin{array}{l}23^{\circ} 25^{\prime} 31^{\prime \prime} \mathrm{S} \\
51^{\circ} 56^{\prime} 19^{\prime \prime} \mathrm{W}\end{array}$ & PR \\
\hline LA-5 & Xantic Hapludox/Haplic Acrisol/ Latossolo Amarelo Distrófico Argissólico & Ariquemes & $\begin{array}{l}9^{\circ} 54^{\prime} 48^{\prime \prime} \mathrm{S} \\
63^{\circ} 02^{\prime} 24^{\prime \prime} \mathrm{W}\end{array}$ & RO \\
\hline PVA-2 & Typic Hapludult/Haplic Acrisol/ Argissolo Vermelho-Amarelo Distrófico & Ariquemes & $\begin{array}{l}9^{\circ} 54^{\prime} 48^{\prime \prime} \mathrm{S} \\
63^{\circ} 02^{\prime} 24^{\prime \prime} \mathrm{W}\end{array}$ & RO \\
\hline LA- 6 & Xantic Eutrudox/Xantic Ferralsol/ Latossolo Amarelo Eutrófico Argissólico & Not identified & - & $\mathrm{SC}$ \\
\hline PVA-3 & Typic Hapludult/Haplic Acrisol/Argissolo Vermelho-Amarelo Distrófico & Capão Bonito & $\begin{array}{l}24^{\circ} 00^{\prime} 21^{\prime \prime} \mathrm{S} \\
48^{\circ} 20^{\prime} 58^{\prime \prime} \mathrm{W}\end{array}$ & SP \\
\hline LV-3 & Typic Acrudox/Geric Ferralsol/ Latossolo Vermelho Acriférrico & Guatapará & $\begin{array}{l}21^{\circ} 29^{\prime} 48^{\prime \prime S} \\
48^{\circ} 02^{\prime} 16^{\prime \prime} \mathrm{W}\end{array}$ & SP \\
\hline LV-4 & Typic Hapludox/Rhodic Ferralsol/ Latossolo Vermelho Distrófico & Piracicaba & $\begin{array}{l}22^{\circ} 43^{\prime} 31^{\prime \prime} \mathrm{S} \\
47^{\circ} 38^{\prime} 57^{\prime \prime} \mathrm{W}\end{array}$ & SP \\
\hline PV & Typic Hapludult/Haplic Acrisol/Argissolo Vermelho Distrófico & Piracicaba & $\begin{array}{l}22^{\circ} 43^{\prime} 31^{\prime \prime} \mathrm{S} \\
47^{\circ} 38^{\prime} 57^{\prime \prime} \mathrm{W}\end{array}$ & SP \\
\hline PVA-4 & Typic Hapludult/Haplic Acrisol/ Argissolo Vermelho-Amarelo Distrófico & Piracicaba & $\begin{array}{l}22^{\circ} 43^{\prime} 31^{\prime \prime} \mathrm{S} \\
47^{\circ} 38^{\prime} 57^{\prime \prime} \mathrm{W}\end{array}$ & SP \\
\hline NV-2 & Typic Kandiudult//Rhodic Ferralsol/ Nitossolo Vermelho Distrófico & Piracicaba & $\begin{array}{l}22^{\circ} 43^{\prime} 31^{\prime \prime S} \\
47^{\circ} 38^{\prime} 57^{\prime \prime} \mathrm{W}\end{array}$ & SP \\
\hline RQ & $\begin{array}{l}\text { Typic Quartzipsamment/Haplic Arenosol/ Neossolo Quartzarênico } \\
\text { Distrófico }\end{array}$ & São Pedro & $\begin{array}{c}4^{\circ} 39^{\prime} 30^{\prime \prime} \mathrm{S} \\
40^{\circ} 35^{\prime} 56^{\prime \prime} \mathrm{W}\end{array}$ & SP \\
\hline LVA & Typic Hapludox/Xantic Ferralsol/ Latossolo Vermelho-Amarelo Distrófico & São Pedro & $\begin{array}{c}4^{\circ} 39^{\prime} 30^{\prime \prime} \mathrm{S} \\
40^{\circ} 35^{\prime} 56^{\prime \prime} \mathrm{W} \\
\end{array}$ & SP \\
\hline
\end{tabular}

analysis) on $\mathrm{Al}^{3+}$ determination in the extract of $\mathrm{KCl}$; and d) Colorimetric methods with eriochrome cyanine $\mathbf{R}$ by flow injection analysis (FIA) according to Zagatto et al. (1981), adapted for the $\mathrm{KCl}$ solution with modifications in the entrances of the FIA system and in eluent volume, following the Al determination by spectrophotometry of the formed colored complex at $\mathrm{pH} 6.4$, and $546 \mathrm{~nm}$ (Figure 1).

Data were submitted to the analyses of descriptive statistics, of correlation and of regression. For the comparison of methods of $\mathrm{Al}^{3+}$ determination the variance analyses and of test of means (Tukey, $P<0.05$ ), were used after the data transformation $(\mathrm{X}+0.5)$.

\section{RESULTS AND DISCUSSION}

There were differences among quantities of $\mathrm{Al}^{3+}$ evaluated by the different methods in the extracts of soil samples in neutral $\mathrm{KCl}$ solution (Table 3). The values of

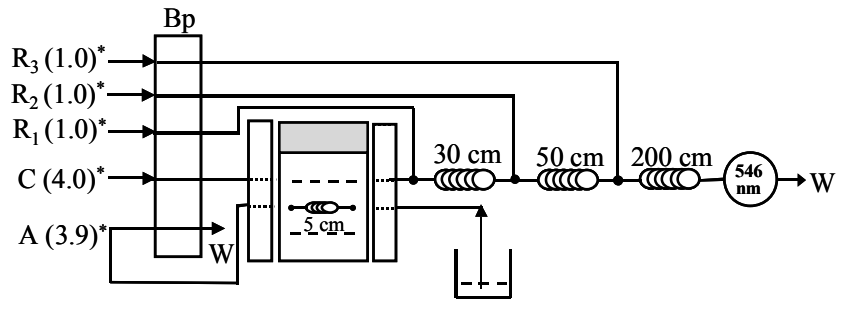

* flow rate $\left(\mathrm{mL} \mathrm{min}^{-1}\right)$

Figure 1 - Flow diagram of the system for determining exchangeable aluminum $\left(\mathrm{Al}^{3+}\right)$ in soil samples, extracted with neutral 1 mol L${ }^{-1} \mathrm{KCl}$ solution. A is the flow, in $\mathrm{mL} / \mathrm{min}$, of $1 \mathrm{~mol} \mathrm{~L}^{-1}$ $\mathrm{KCl}$ extractant containing $\mathrm{Al}^{3+}$ extracted from the soil sample; $\mathbf{C}$ is the flow of carrier $\mathrm{KCl}$ solution; $\mathbf{R}_{\mathbf{1}}$ is the flow of $20 \mathrm{~g} \mathrm{~L}^{-1}$ ascorbic acid solution (prepared just before the analysis); $\mathbf{R}_{2}$ is the flow of $0.2 \mathrm{~g} \mathrm{~L}^{-1}$ eriochrome cyanine $\mathrm{R}$ solution (prepared just before the analysis by dilution of $2 \mathrm{~g} \mathrm{~L}^{-1}$ stock solution, $\mathrm{pH} 2.8$, with deionizated water); $\mathbf{R}_{\mathbf{3}}$ is the flow of $4 \mathrm{~mol} \mathrm{~L}^{-1}$ ammonium acetate buffer solution, pH 6.4; Bp, peristaltic pump; $\mathbf{W}$, waste . 
Table 2 - Chemical properties of soil samples of the $0-0.2 \mathrm{~m}$ layer.

\begin{tabular}{|c|c|c|c|c|c|c|c|c|c|c|c|}
\hline $\begin{array}{l}\text { Soil } \\
\text { Sample }\end{array}$ & $\begin{array}{c}\mathrm{pH} \\
\mathrm{CaCl}_{2}\end{array}$ & $\begin{array}{c}\text { Organic } \\
\text { mater }\end{array}$ & Resin P & $\mathrm{K}^{+}$ & $\mathrm{Ca}^{2+}$ & $\mathrm{Mg}^{2+}$ & ${ }^{(1)} \mathrm{Na}^{+}$ & $\mathrm{H}^{+}+\mathrm{Al}^{3+}$ & $\begin{array}{c}\text { Sum of } \\
\text { bases }\end{array}$ & CEC & $\begin{array}{c}\text { Base } \\
\text { saturation }\end{array}$ \\
\hline & & $\mathrm{g} \mathrm{dm}^{-3}$ & $\mathrm{mg} \mathrm{dm}{ }^{-3}$ & \multicolumn{7}{|c|}{ - $\mathrm{mmol}_{\mathrm{c}} \mathrm{dm}^{-3}$} & $\%$ \\
\hline GX & 4.56 & 12.7 & 11.0 & 1.45 & 27.2 & 6.8 & 1.1 & 36.2 & 36.4 & 72.6 & 50.1 \\
\hline LA- 1 & 3.82 & 25.2 & 5.0 & 0.89 & 2.1 & 1.3 & 0.2 & 95.2 & 4.5 & 99.7 & 4.5 \\
\hline LV-1 & 5.52 & 22.2 & 4.9 & 2.84 & 26.4 & 14.6 & 0.3 & 21.3 & 44.1 & 65.4 & 67.4 \\
\hline LV-2 & 4.10 & 27.4 & 3.5 & 0.78 & 1.2 & 1.1 & 0.2 & 67.3 & 3.3 & 70.6 & 4.7 \\
\hline LA-2 & 3.78 & 22.9 & 5.0 & 0.71 & 4.8 & 2.2 & 0.5 & 50.8 & 8.4 & 59.2 & 14.2 \\
\hline PVA-1 & 3.98 & 25.0 & 3.3 & 0.74 & 8.1 & 2.5 & 0.8 & 40.5 & 12.1 & 52.7 & 23.1 \\
\hline LA-3 & 3.91 & 37.9 & 5.8 & 1.06 & 9.2 & 8.3 & 1.2 & 81.9 & 19.8 & 101.7 & 19.5 \\
\hline LA-4 & 4.72 & 32.6 & 3.9 & 1.92 & 21.2 & 6.0 & 0.5 & 28.6 & 29.7 & 58.3 & 50.9 \\
\hline NV-1 & 4.64 & 14.9 & 1.4 & 0.99 & 17.1 & 7.0 & 0.3 & 45.2 & 25.4 & 70.6 & 35.9 \\
\hline LA-5 & 4.52 & 19.9 & 6.9 & 2.62 & 15.5 & 3.6 & 0.4 & 30.3 & 22.1 & 52.4 & 42.2 \\
\hline PVA-2 & 4.54 & 22.4 & 4.9 & 1.32 & 7.9 & 3.6 & 0.2 & 24.6 & 13.1 & 37.7 & 34.8 \\
\hline LA- 6 & 4.58 & 24.1 & 13.6 & 2.13 & 36.3 & 10.6 & 0.8 & 46.7 & 49.8 & 96.5 & 51.6 \\
\hline PVA-3 & 4.25 & 40.8 & 1.3 & 2.33 & 4.3 & 2.4 & 0.2 & 108.6 & 9.2 & 117.8 & 7.8 \\
\hline LV-3 & 4.63 & 30.1 & 4.3 & 1.07 & 13.4 & 8.7 & 0.2 & 41.4 & 23.3 & 64.7 & 36.0 \\
\hline LV-4 & 4.57 & 27.9 & 45.4 & 3.84 & 16.8 & 10.8 & 0.3 & 51.8 & 31.8 & 83.6 & 37.9 \\
\hline PV & 4.72 & 27.9 & 2.8 & 0.70 & 22.3 & 8.1 & 0.2 & 40.4 & 31.4 & 71.8 & 43.7 \\
\hline PVA-4 & 4.28 & 25.1 & 3.6 & 0.74 & 10.3 & 3.5 & 0.3 & 38.3 & 14.8 & 53.1 & 27.8 \\
\hline NV-2 & 5.28 & 45.0 & 10.2 & 2.16 & 50.0 & 14.1 & 0.2 & 34.3 & 66.6 & 100.9 & 66.0 \\
\hline RQ & 3.96 & 17.9 & 2.8 & 0.71 & 1.8 & 0.7 & 1.0 & 43.9 & 4.6 & 48.5 & 9.5 \\
\hline LVA & 4.43 & 36.1 & 4.9 & 1.95 & 7.9 & 3.3 & 0.6 & 48.1 & 14.0 & 62.1 & 22.5 \\
\hline
\end{tabular}

${ }^{(1)}$ Sodium extracted by $0.05 \mathrm{~mol} \mathrm{~L}^{-1} \mathrm{HCl}+0.0125 \mathrm{~mol} \mathrm{~L}^{-1} \mathrm{H}_{2} \mathrm{SO}_{4}, 1: 5(\mathrm{v} / \mathrm{v})$ soil/solution ratio. Other chemical analyses as described in Raij et al. $(1987 ; 2001)$.

$\mathrm{Al}^{3+}$, in $\mathrm{mmol}_{\mathrm{c}} \mathrm{dm}^{-3}$, in the acid soil samples with $\mathrm{pH}$ ranging from 3.82 to 5.52 (Table 2), varied from 0.15 to 14.71 (median of 4.22) when determined by titration; from 0 to 18.75 (median of 3.94 ) by aluminon colorimetric method; from 0 to 18.27 (median of 4.00 ) by aluminon colorimetry with addition of ascorbic acid; and from 0 to 15.24 (mean of 4.17 and median of 2.66) by eriochrome cyanine R colorimetry in FIA system.

Quadratic relationships were verified between the $\mathrm{Al}^{3+}$ concentrations obtained by titration and those of the colorimetric methods (Figure 2), because in the soil samples with $\mathrm{Al}^{3+}>10 \mathrm{mmol}_{\mathrm{c}} \mathrm{dm}^{-3}$ the colorimetric methods gave higher values than by the titration method, mainly in those with aluminon (up to $18.75 \mathrm{mmol}_{\mathrm{c}} \mathrm{dm}^{-3}$, e.g., soil samples LA-1 and PVA-3), owing to the strong acidity of these samples.

For the soil samples with $\mathrm{Al}^{3+}$ concentration between 1 to $10 \mathrm{mmol}_{\mathrm{c}} \mathrm{dm}^{-3}$, generally, the modified aluminon colorimetric method with the addition of ascorbic acid and the titrimetric method did not differ from each other. However, the aluminon colorimetric method provided the highest $\mathrm{Al}^{3+}$ values, and the eriochrome cyanine $\mathrm{R}$ colorimetric methods by FIA gave the lowest values. The addition of ascorbic acid minimized the interference of $\mathrm{Fe}^{3+}$, in the $\mathrm{KCl}$ extracts, on the $\mathrm{Al}^{3+}$ analysis by the aluminon color reagent. The $\mathrm{Al}^{3+}$ analysis by the eriochrome cyanine $\mathrm{R}$ with FIA showed

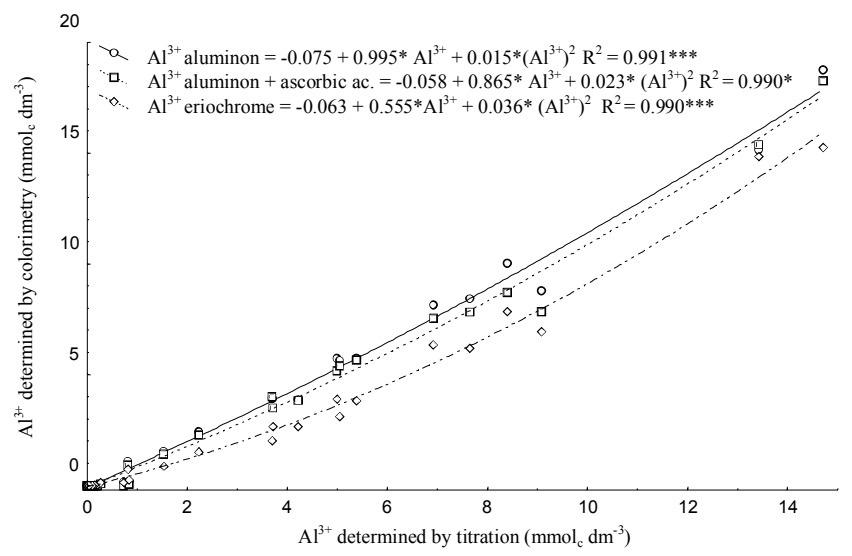

Figure 2 - Relationships between the exchangeable aluminum $\left(\mathrm{Al}^{3+}\right)$ determined by titrimetric method (alkaline titration followed by acid back-titration), and by colorimetric methods of $\mathrm{Al}^{3+}$ determination, aluminon, aluminon plus ascorbic acid (by conventional colorimetry), and eriochrome cyanine $\mathrm{R}$ (by flow injection analysis FIA), respectively, in soil samples from different Brazilian regions, extracted with neutral $1 \mathrm{~mol} \mathrm{~L}^{-1} \mathrm{KCl}$ solution.

low efficiency due to the low concentration of the colorimetric reagent, as this method was adapted from that for analysis of total aluminum in vegetable material (Zagatto et al., 1981), for which the relative Al concentration in the extract is much higher than in $\mathrm{KCl}$ soil extract. 
Table 3 - Concentration of exchangeable aluminum $\left(\mathrm{Al}^{3+}\right)$, extracted with neutral $1 \mathrm{~mol} \mathrm{~L}^{-1} \mathrm{KCl}$ solution, determined by the titrimetric method (alkaline titration followed by acid back-titration), and by aluminon colorimetric method, modified aluminon colorimetric method with ascorbic acid addition through conventional colorimetry, and eriochrome cyanine $\mathrm{R}$ colorimetric method through flow injection analysis (FIA).

\begin{tabular}{|c|c|c|c|c|}
\hline \multirow{2}{*}{ Soil sample } & \multirow{2}{*}{ Titration } & \multicolumn{2}{|c|}{ Aluminon } & \multirow{2}{*}{$\begin{array}{l}\text { Eriochrome } \\
\quad(\text { FIA })\end{array}$} \\
\hline & & without ascorbic acid & with ascorbic acid & \\
\hline \multicolumn{5}{|c|}{$-\mathrm{mmol}_{\mathrm{c}} \mathrm{dm}^{-3}$} \\
\hline GX & $3.71 \mathrm{ab}^{\#}$ & $3.92 \mathrm{a}$ & $3.50 \mathrm{~b}$ & $2.65 \mathrm{c}$ \\
\hline LA- 1 & $13.42 \mathrm{~b}$ & $15.14 \mathrm{a}$ & $15.38 \mathrm{a}$ & $14.85 \mathrm{a}$ \\
\hline LV-1 & $0.20 \mathrm{a}$ & $0.00 \mathrm{~b}$ & $0.00 \mathrm{~b}$ & $0.00 \mathrm{~b}$ \\
\hline LV-2 & $6.92 \mathrm{c}$ & $8.14 \mathrm{a}$ & $7.56 \mathrm{~b}$ & $6.35 \mathrm{~d}$ \\
\hline LA-2 & $7.65 \mathrm{~b}$ & $8.43 \mathrm{a}$ & $7.83 \mathrm{~b}$ & $6.19 \mathrm{c}$ \\
\hline PVA-1 & $4.99 \mathrm{~b}$ & $5.71 \mathrm{a}$ & $5.16 \mathrm{~b}$ & $3.90 \mathrm{c}$ \\
\hline LA-3 & $9.08 \mathrm{a}$ & $8.78 \mathrm{a}$ & $7.85 \mathrm{~b}$ & $6.94 \mathrm{c}$ \\
\hline LA-4 & $0.73 \mathrm{a}$ & $0.15 \mathrm{~b}$ & $0.0 \mathrm{~b}$ & $0.13 \mathrm{~b}$ \\
\hline NV-1 & $3.69 \mathrm{a}$ & $3.94 \mathrm{a}$ & $3.99 \mathrm{a}$ & $2.03 \mathrm{~b}$ \\
\hline LA-5 & $1.53 \mathrm{a}$ & $1.54 \mathrm{a}$ & $1.40 \mathrm{a}$ & $0.85 \mathrm{~b}$ \\
\hline PVA-2 & $0.83 \mathrm{a}$ & $0.19 \mathrm{~b}$ & $0.05 \mathrm{~b}$ & $0.25 \mathrm{~b}$ \\
\hline LA- 6 & $4.22 \mathrm{a}$ & $3.86 \mathrm{ab}$ & $3.83 \mathrm{~b}$ & $2.65 \mathrm{c}$ \\
\hline PVA-3 & $14.71 \mathrm{c}$ & $18.75 \mathrm{a}$ & $18.27 \mathrm{a}$ & $15.24 \mathrm{~b}$ \\
\hline LV-3 & $0.26 \mathrm{a}$ & $0.29 \mathrm{a}$ & $0.07 \mathrm{a}$ & $0.11 \mathrm{a}$ \\
\hline LV-4 & $2.23 \mathrm{a}$ & $2.42 \mathrm{a}$ & $2.28 \mathrm{a}$ & $1.50 \mathrm{~b}$ \\
\hline $\mathrm{PV}$ & $0.81 \mathrm{a}$ & $1.09 \mathrm{a}$ & $0.92 \mathrm{a}$ & $0.72 \mathrm{a}$ \\
\hline PVA-4 & $5.38 \mathrm{a}$ & $5.73 \mathrm{a}$ & $5.66 \mathrm{a}$ & $3.84 \mathrm{~b}$ \\
\hline NV-2 & $0.15 \mathrm{a}$ & $0.00 \mathrm{~b}$ & $0.00 \mathrm{~b}$ & $0.00 \mathrm{~b}$ \\
\hline RQ & $8.39 \mathrm{~b}$ & $10.04 \mathrm{a}$ & $8.72 \mathrm{~b}$ & $7.84 \mathrm{c}$ \\
\hline LVA & $5.04 \mathrm{a}$ & $5.64 \mathrm{a}$ & $5.41 \mathrm{a}$ & $3.10 \mathrm{~b}$ \\
\hline
\end{tabular}

${ }^{\#}$ Means followed by same letters within a soil sample are not significantly different according to the mean separation Tukey test $(P<0.05)$ (Variance analysis with $\mathrm{X}+0.5$ data transformation).

Brauner (1966) observed, unlike the results of the present work, that in samples with low $\mathrm{Al}^{3+}$ concentration the difference between the values obtained by titrimetric and aluminon colorimetric was higher than for samples with high concentration and this difference was attributed to the interference of $\mathrm{Ca}$ and $\mathrm{Fe}$ in the aluminon method. This $\mathrm{Ca}$ derives from the calcium chloride solution used as extractant and the $\mathrm{Fe}$ from the tioglycolic acid employed in the reagent solution. To remove the interference of these two elements during the $\mathrm{Al}^{3+}$ determination by the aluninon colorimetric method, Frink \& Peech (1962) had proposed the exclusion of the calcium chloride as extractant and the substitution of tioglycolic acid, in the reagent solution, with hydroxylamine hydrochloride. Despite of this, the difference between results observed in the present study and those of Brauner (1966) is also due to the fact that the values of $\mathrm{Al}^{3+}$ obtained by titration by the last author, are actually equal to the titratable acidity, since the concentration was obtained without back-titration, after addition of $\mathrm{NaF}$. The aluminon colorimetric method described by Wolf (1982) and used in the present work was similar to that proposed by Frink \& Peech (1962).
The $\mathrm{Al}^{+3}$ determination by the titrimetric method presented standard deviations (SD, mean of three replicates for each soil sample) between 0.06 to $0.28 \mathrm{mmol}_{\mathrm{c}} \mathrm{dm}^{-3}$ (except for soil sample LA-2, with a SD of $\left.0.55 \mathrm{mmol}_{\mathrm{c}} \mathrm{dm}^{-3}\right)$, and coefficients of variation $(\mathrm{CV} \%$, mean of three replicates for each soil sample) between 1.3 to $20.8 \%$ (except for sample $\mathrm{LV}-3, \mathrm{CV} \%=43.3$ ). For the colorimetric methods using the aluminon and aluminon + ascorbic acid reagent, the SD varied between 0.04 to $0.68 \mathrm{mmol}_{\mathrm{c}} \mathrm{dm}^{-3}, 0.07$ to $0.23 \mathrm{mmol}_{\mathrm{c}} \mathrm{dm}^{-3}$, and the $\mathrm{CV} \%$ between $0.7^{\mathrm{c}}$ to $33.2,0.8$ to 7.4 (excluding samples LA-4 and LV-3, CV $>80 \%$ due to the inverse relation between $\mathrm{Al}$ concentration and $\mathrm{CV} \%$ ), respectively. The lower and narrow range values of SD and $\mathrm{CV} \%$ for the method with aluminon + ascorbic acid is also associated to the fact that ion interferences, mainly the $\mathrm{Fe}^{3+}$ ion, which is quite suppressed with ascorbic acid. Using the FIA system with the eriochrome cyanine $\mathrm{R}$ reagent, the values of $\mathrm{SD}$ and $\mathrm{CV} \%$ varied between 0.03 and $0.46 \mathrm{mmol}_{\mathrm{c}} \mathrm{dm}^{-3}$ and 0.7 and 19.7, respectively. Positive correlations $(P<0.05)$ were observed between SD and $\mathrm{Al}^{3+}$ concentration in $\mathrm{KCl}$ extracts for all colorimetric methods as there was intrinsic relationship between intensity of developed color and $\mathrm{Al}$ content in the extract, 
and conversely, the titrimetric method presented negative correlations between $\mathrm{CV} \%$ and $\mathrm{Al}^{3+}$ concentration, due to the difficulty in the observation of the end-point.

Despite of this, for most of the acid soil samples of $\mathrm{pH}$ ranging from 3.8 to 4.7 , the relative low values of SD and CV\% indicate that all these tested methods presented good reproductibility for the analytical determination of the $\mathrm{Al}^{3+}$. The titrimetric method, phenolphthalein being used as indicator, presented a limitation due to the difficulty in observing the end-point and the analytic moroseness, due to the need of two step analysis (back-titration), which limits the number of samples to be analyzed by each batch. The $\mathrm{Al}^{3+}$ values given by titration may be imprecise and untruthful in relation to solutions of known Al concentration (Logan et al., 1985). Raij et al. (2001) have proposed the $\mathrm{Al}^{3+}$ determination, when necessary, by some specific methods, such as the spectrophotometry with orange of xylenol in extracts of $\mathrm{NH}_{4} \mathrm{Cl}$ or even by plasma spectrometry (ICP-AES) in $\mathrm{KCl}$ or $\mathrm{NH}_{4} \mathrm{Cl}$ extracts.

Both aluminon colorimetric methods presented difficulties for cleaning the glassware and tubes in contact with the aluminon reagent. All glassware was stained with a rose-red coloration, mainly in the quartz vessel of the spectrophotometry, producing accumulative effect and provoking systematic errors for the $\mathrm{Al}^{3+}$ determination in the soil extracts. The FIA system, employed for Al determination by eriochrome cyanine $\mathrm{R}$ method, should also be carefully washed after the analysis to avoid the discoloration, although slow, of the polyethylene tubes by the colorimetric reagent (Zagatto et al., 1981).

Among colorimetric methods, in relation to operationality, the eriochrome cyanine $\mathrm{R}$ colorimetric method, with FIA system presented the best analytical quickness (allowing analysis up to 50 samples per hour), easiness and sensibility. In addition, the chemical analysis using FIA system can also turn simultaneous or sequential analysis of several elements easier (Kronka, 1996; Kachurina et al., 2000). The eriochrome-FIA procedure, with some modifications (improvements are needed for soil samples), should be preferred over the titration method when operational gains are the main aim in routine analysis of soil samples; nevertheless when the target is the research, titration should be used, because, despite this moroseness, with back-titration the procedure is specific for $\mathrm{Al}^{3+}$ ions.

\section{REFERENCES}

BARNHISEL, R.; BERTSCH, P.M. Aluminum. In: PAGE, A.L.; MILLER, R.H.; KEENEY, D.B. (Ed.) Methods of soil analysis: Part 2. Chemical and microbiological properties. Madison: ASA, 1982. p.275-300.

BERTSCH, P.M.; ALLEY, M.M.; ELLMORE, T.L. Automated aluminum analysis with the aluminon methods. Soil Science Society of America Journal, v.45, p.666-667, 1981.

BRAUNER, J.L. Extração e determinação do alumínio "trocável” do solo; variação no seu teor influenciado pela aplicação de carbonato de cálcio. Piracicaba: USP/ESALQ, 1966. 34p. (Dissertação - Mestrado)
COSCIONE, A.R.; ANDRADE, J.C.; RAIJ. B. van. Revisiting titration procedures for the determination of exchangeable acidity and exchangeable aluminum in soils. Communications in Soil Science and Plant Analysis, v.29, p.1973-1982, 1998.

EMBRAPA. Centro Nacional de Pesquisa de Solos. Sistema brasileiro de classificação de solos. Brasília: Embrapa Produção de Informação; Rio de Janeiro: Embrapa Solos, 1999. 412p.

ESTADOS UNIDOS. Department of Agriculture. Soil taxonomy: a basic system of soil classification form making and interpreting soil surveys. Washington: USDA, 1999. 869p. (Handbook, 436)

FAO. Soil map of the world. Revised legend with corrections. Rome: FAO; UNESCO; Wageningen: ISRIC, 1994. 140p. (World Resources Report, 60)

FRINK, C.R.; PEECH, M. Determination of aluminum in soil extracts. Soil Science, v.93, p.317-324, 1962.

HAWKE, D.J.; POWELL, H.K.J. Flow-injection analysis applied to the kinetic determination of reactive (toxic) aluminum: comparison of chromophores. Analytica Chimica Acta, v.299, p.257-268, 1994.

HIRADATE, S.; TANIGUCHI, S.; SAKURAI, K. Aluminum speciation in aluminum-silica solutions and potassium chloride extracts of acidic soils. Soil Science Society of America Journal, v.62, p.630-636, 1998.

KACHURINA, O.M.; ZHANG, H.; RAUN, W.R.; KRENZER, E.G. Simultaneous determination of soil aluminum, ammonium- and nitratenitrogen using $1 \mathrm{M}$ potassium chloride extraction. Communications in Soil Science and Plant Analysis, v.31, p.893-903, 2000.

KISSEL, D.E.; GENTZSCH, E.P.; THOMAS, G.W. Hydrolysis of nonexchangeable acidity in soils during salt extractions of exchangeable acidity. Soil Science, v.111, p.293-297, 1971.

KRONKA, E.A.M. Determinação multielementar em sistemas de fluxo: amônio e ortofosfato, alumínio e ferro em digeridos vegetais. Piracicaba: USP/CENA, 1996. 107p. (Tese - Doutorado)

LOGAN, K.A.B.; FLOATE, M.J.S.; IRONSIDE, A.D. Determination of exchangeable acidity and exchangeable aluminum in hill soils: Part II. Exchangeable aluminum. Communications in Soil Science and Plant Analysis, v.16, p.309-314, 1985.

MARSCHNER, H. Mineral nutrition of higher plants. 2.ed. London: Academic Press, 1997. 889p.

McLEAN, E.O. Aluminum. In: BLACK, C.A. (Ed.) Methods of soil analysis: Part 2. Chemical methods. Madison: ASA, 1965. p.978-998.

OATES, K.M.; KAMPRATH, E.J. Soil acidity and liming: I. Effect of the extracting solution cation and $\mathrm{pH}$ on the removal of aluminum from acid soils. Soil Science Society of America Journal, v.47, p.686-689, 1983.

PAVAN, M.A. Alumínio em solos ácidos do Paraná: relação entre o alumínio não-trocável, trocável e solúvel, com o $\mathrm{pH}$, CTC, porcentagem de saturação de $\mathrm{Al}$ e matéria orgânica. Revista Brasileira de Ciência do Solo, v.7, p.39-46, 1983.

RAIJ, B. van; ANDRADE, J.C.; CANTARELLA, H.; QUAGGIO, J.A. Análise química para avaliação da fertilidade de solos tropicais. Campinas: Instituto Agronômico, 2001. 285p.

RAIJ, B. van; QUAGGIO, J.A.; CANTARELLA, H.; FERREIRA, M.E.; LOPES, A.S.; BATAGLIA, O.C. Análise química do solo para fins de fertilidade. Campinas: Fundação Cargill, 1987. 170p.

REIS, B.F. Determinação colorimétrica de alumínio em águas naturais, plantas e solos por injeção em fluxo contínuo. Piracicaba: USP/ESALQ, 1978. 64p. (Dissertação - Mestrado)

THOMAS, G.W.; HARGROVE, W.L. The chemistry of soil acidity. In: ADAMS, F. (Ed.) Soil acidity and liming. Madison: ASA, CSSA, SSSA, 1984. cap.1, p.3-56.

WOLF, B. An improved universal extracting solution and its use for diagnosing soil fertility. Communications in Soil Science and Plant Analysis, v.13, p.1005-1033, 1982.

ZAGATTO, E.A.G.; JACINTHO, A.O.; REIS, B.F.; KRUG, F.J.; BERGAMIN FILHO, H.; PESSENDA, L.C.R.; MORTATTI, J.; GINÉ, M.F. Manual de análises de plantas e águas empregando sistemas de injeção em fluxo. Piracicaba: CENA, Seção de Radioquímica e Química Analítica, 1981. p.19-21.

$\overline{\text { Received August }}$ 19, 2002

Accepted April 16, 2003 